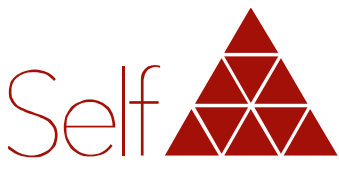

Revista do Instituto Junguiano de Săo Paulo

\title{
Filhos da mãe - Animus da mãe na vida do filho
}

\author{
Irene GAETA
}

São Paulo, SP, Brasil.

\section{Resumo}

Este artigo tem por objetivo refletir sobre as pessoas nascidas no contexto da ausência paterna, os "filhos da mãe". A partir do entendimento do inestimável valor do fenômeno relacional humano e do funcionamento psíquico, este trabalho aplica os princípios de anima e animus propostos por Jung, considerando que tais princípios explicam a dualidade entre os sexos, por um lado, e dão sentido à própria experiência subjetiva, por outro. Discute-se também a diferenciação entre os filhos da mulher com um ego estruturado e uma boa relação com seu lado masculino e os filhos da mulher com o animus atuando de modo autônomo. Parte-se do pressuposto de que é preciso olhar para a biologia e para a psicologia de maneira integrada, pois se o cérebro molda a psique, a psique também molda o cérebro. Não há como supor que o homem seja regido por logos e a mulher por Eros, mesmo que sejam entendidos como elementos que compõem tanto o masculino quanto o feminino. Capacidade de decisão, iniciativa, coragem e honestidade nascem do lado positivo do animus que, no seu aspecto maior, personifica uma elevada profundidade espiritual.

Conflito de interesses:

A autora declara não haver nenhum interesse profissional ou pessoal que possa gerar conflito de interesses em relação a este manuscrito.

\section{Descritores}

ego, psicologia junguiana, complexo materno.

Recebido: 30 out 2018; 1a revisão: 18 dez 2018; 2a revisão: 29 jan 2019; aprovado: 31 jan 2019; aprovado para publicação: 27 fev 2019. 


\title{
Mother's children - Mother's animus in the life of her children
}

\begin{abstract}
This paper aims to reflect on people born in the context of paternal absence, the "mother's children". From the understanding of the priceless value of human relational phenomena and psychic functioning, this paper applies the principles of anima and animus proposed by Jung, considering that such principles explain the duality between sexes, on one hand, and give meaning to the experience itself, on the other. It also discusses the differentiation between the children of a woman with a structured ego and a good relation with his masculine side and the children of a woman with the animus acting autonomously. The assumption is that biology and psychology must be looked at integrated, for if the brain shapes the psyche, the psyche also shapes the brain. There is no way to suppose that men be ruled by logos and women by Eros, even though they be understood as elements that make up both the masculine and the feminine. The capacity for decision, initiative, courage and honesty are born from the positive side of the animus, which in its greater aspect embodies a superior spiritual depth.

\section{Descriptors}

ego, Jungian psychology, maternal complex.
\end{abstract}




\section{Los hijos de la Madre - Animus de la madre en la vida de los hijos}

\section{Resumen}

Este artículo tiene el objetivo de reflexionar sobre las personas nacidas en el contexto de la ausencia paterna, "los hijos de la madre". A partir de la comprensión del inestimable valor del fenómeno relacional humano y del funcionamiento psíquico, este trabajo aplica los principios de anima y animus propuestos por Jung, considerando que tales principios explican la dualidad entre los sexos, por un lado, y dan sentido a la propia experiencia subjetiva, por otro. Se discute también la diferenciación entre los hijos de una mujer con un ego estructurado y una buena relación con su lado masculino, y los de una mujer con el animus actuando de modo autónomo. Se parte de la premisa de que hay que contemplar a la biología y a la psicología integradamente, pues si el cerebro modela la psique, la psique también modela el cerebro. No hay cómo suponer que el hombre sea regido por logos y la mujer por Eros, aunque sean entendidos como elementos que componen tanto lo masculino como lo femenino. La capacidad de decisión, la iniciativa, el coraje y la honestidad nacen del lado positivo del animus que, en su aspecto mayor, personifica una elevada profundidad espiritual.

\section{Descriptores}

ego, psicología junguiana, complejo materno. 


\section{Introdução}

"Quando o pai é ausente, caímos mais prontamente nos braços da mãe" (Hilman, 1998).

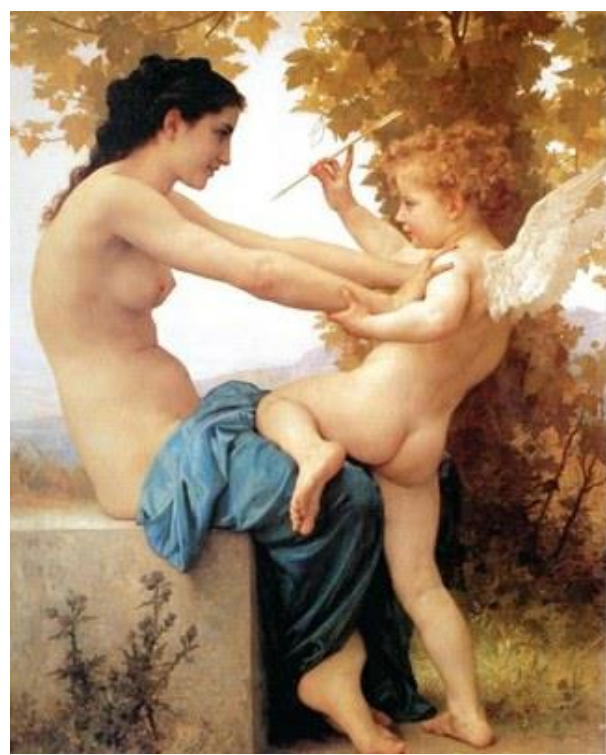

Figura 1. Young Girl Defending Herself against Eros, 1880. Reproduzido de Linkmesh, http://www.linkmesh.com/imagenes/temas/angelitos/cupido_pelea.jpg, 2019.

A ausência paterna não é um fenômeno recente. Entretanto, há um aumento no número de casos e diversificação na origem de tal lacuna: produção independente, fecundação in vitro e engenharia genética são manifestações concretas do fenômeno do poder e da autonomia - eventualmente narcísicos - assumidos pela mulher, em quem se observa uma maior ênfase na atuação do animus em termos de relação com o mundo externo. Essa realidade motiva a questionar o que será dos indivíduos nascidos nesse contexto, os "filhos da mãe", e como será a nova sociedade regida pelo complexo materno. Esta reflexão traz uma série de questionamentos que pretendem contribuir para a compreensão desse fenômeno e de suas consequências. Cabe ainda, no contexto a ser discutido, estabelecer uma diferenciação entre o filho da mulher que tem um ego estruturado e uma boa relação com seu lado masculino e o filho da mulher que tem o animus atuando de modo autônomo. A mãe (a Grande Mãe) como 
aquela que dá e alimenta, com a própria vida, e exige que o filho se comporte como filho dependente (Figura 1).

Para demonstrar o modo como isso ocorre, toma-se o caso hipotético de uma mãe, cuja inconsciência torna difícil para a criança alcançar uma distância satisfatória, que favoreça a tomada de decisões e a descoberta da própria identidade. Neste caso, pode ser que a criança não consiga desenvolver um ego forte o bastante para vencer a batalha com o dragão, como é o caso de dependentes químicos. O "filho da mãe" pode desenvolver um comportamento simbiótico exagerado. Muitas vezes essa ligação aparece como a síndrome de amor romântico. Ao apaixonar-se, além do complexo materno do indivíduo estar constelado, também sua carga histórico-social ganha relevo. Há casos nos quais o relacionamento amoroso pode colocar em xeque a individualidade dos parceiros, impedindo que cada um seja quem realmente é. Para essas pessoas, relacionar-se em profundidade pode se tornar um risco para o ego a ser evitado a todo custo ou uma expectativa de fusão simbiótica com o outro, promovendo uma regressão tão ameaçadora quanto.

O mito do herói na batalha com o dragão é de extrema relevância para a psicologia analítica, uma metáfora do desenvolvimento do ego a partir do inconsciente. A criatura da narrativa pode ser imaginada como uma cobra alada, um monstro que pertence tanto à terra quanto ao céu, mais ao mundo dos monstros do que ao dos seres humanos. O dragão ilustra a força criativa e destruidora originada no inconsciente profundo da psique humana, aquilo que quer existir e que quer engolir tudo o que ousa nascer, impedindo que se chegue à consciência, mantendo o indivíduo - ou o devolvendo - em um nível arcaico. Aqui matéria, mãe e inconsciente se equivalem. $O$ indivíduo corre sério risco de se dobrar a essa força e, se isso ocorrer, estará fadado à inconsciência ou a desenvolver uma estrutura de personalidade nas diversas manifestações do puer, para sempre. Por outro lado, a conquista do dragão libera um tesouro. Somente desenvolvendo a autonomia, o filho da mãe terá chance de salvar seu ego de ser devorado pelo dragão.

Mas que fator projetante é este? O Oriente dá-lhe o nome de "tecedeira", ou maia, isto é, a dançarina geradora de ilusões.

Se não soubéssemos disto há bastante tempo mediante os sonhos, esta interpretação nos colocaria na pista certa: aquilo que encobre, que enlaça e absorve, aponta inelutavelmente para a mãe, isto é, para a relação do filho com a mãe real, com a imagem desta, e com a mulher que deve tornar-se mãe para ele. Seu Eros é passivo, como o é de uma criança: ele espera ser 
captado, sugado, velado e tragado. Ele procura de certo modo, a órbita protetora e nutridora da mãe, a condição de criança de peito, distanciada de qualquer preocupação com a vida e na qual o mundo exterior lhe vem ao encontro e até mesmo lhe impõe sua felicidade. Por isto não é de espantar que o mundo real se the retraia. (Jung, 1951/201 1, p. 9, § 20) (Destaques do autor).

Mulheres desta geração sabem que a jornada de uma mulher à consciência deve ser diferente da jornada de um homem, cujo mito de matar o dragão (isto é, a separação da mãe) é atualmente obsoleto. $O$ perigoso dragão ou o aspecto negativo do arquétipo do feminino não pode ser aniquilado - ele se oculta dentro de todas as mulheres e de todos os homens, embora de maneiras diferentes.

Se não for conscientemente aceita, essa destruição reprimida dentro da psique de mulheres e de homens devastaria nossa civilização com tal vingança que nenhum herói seria capaz de interrompê-la. O único meio de apaziguar o dragão é reconhecer que somos parte da sua natureza e que precisamos nos relacionar com esta parte em lugar de tentar combatê-la e controlá-la.

\section{Anima e animus hoje}

Para se compreender o fenômeno relacional humano e o funcionamento psíquico é de inestimável valor aplicar os princípios de anima e animus propostos por Jung. Na análise, deve-se adequar, flexibilizar e ampliar tais conceitos, uma vez que o discurso recebe influências dos diferentes contextos históricosociais. Jung (1987) propôs o termo anima para nomear a porção feminina (contrassexual) que compõe a personalidade masculina; e animus para designar a porção masculina existente na personalidade feminina. Se por um lado, Jung desejava explicar a dualidade entre os sexos, por outro, queria dar sentido à própria experiência subjetiva.

Considerando as novas formas de relacionamento e a multiplicidade de temas ligados à sexualidade na nossa contemporaneidade, a visão clássica de Jung está exposta a críticas, mas a funcionalidade de sua teoria é indiscutível. Afinal, quem não continua projetando e se encantando com a ideia de que algo ou outra pessoa o complete? Assim, é legítimo rever os conceitos teóricos e atualizá-los, adaptando-os ao contexto sociocultural atual. Se antes as possibilidades de vivenciar a sexualidade eram restritas em função de atributos estreitos 
delimitadores de masculino e feminino, hoje não se pode dizer o mesmo.

A compreensão das questões de gênero e sexualidade deve ser ampliada, uma vez que elas demarcam identidades e subjetividades que, por sua vez, estão estruturadas sobre dinâmicas psíquicas e pressupostos localizados em pontos específicos de tempo e espaço. Além disso, há uma linha que separa o individual do coletivo que deve ser mais claramente percebida. O gênero e as hierarquias de gênero que legitimam posições de poder no campo social - é domínio do coletivo e está relacionado ao corpo e à sua apresentação social, ao material; a sexualidade corresponde às instâncias do desejo ligadas à fantasia e, portanto, diz respeito à obtenção de prazer, ao subjetivo.

Apesar de suportar longas críticas, tais questões são absolutamente relevantes ao se pensar nos conceitos de anima e animus na contemporaneidade. Por isso, justifica-se um esforço, no sentido de compreender suas características arquetípicas e sua qualidade de manifestação.

Sobre o uso da expressividade no atendimento

Um olhar mais tradicional percebe os pares contrassexuais como responsáveis pela paixão e pelo fascínio, como arquetípicos e como uma espécie e ligação do mundo consciente com o inconsciente. Segundo Jung (1951/2011),

Propus o termo anima porque o mesmo deve designar algo de específico para o qual o vocábulo alma é geral e vago. $O$ fato que se exprime no conceito de anima é um conteúdo sumamente dramático do inconsciente. Nem de longe exprime seu caráter vital. [...] O fator determinante das projeções e a anima, onde quer que se manifeste, aparece personificada, mostrando desse modo que ela possui todas as qualidades características do feminino. É uma produção espontânea do inconsciente. Não se trata de uma figura substitutiva da mãe, pelo contrário: a impressão de que as qualidades numinosas que tornam a imagem da mãe tão poderosa originam-se do arquétipo coletivo de anima, que se encarna de novo em cada criança do sexo masculino. Assim como a mãe é o primeiro receptáculo do fator determinante de projeções do filho, assim também é o pai para a filha (Jung, 1951/2011, p. 11, § 25-26).

Sobre o arquétipo de anima, Jung (1987) afirma que "há uma imagem coletiva da mulher no inconsciente do homem, com o 
auxílio do qual ele pode compreender a natureza da mulher" ( $p$. 77). Emma Jung (1995), também representante da visão clássica, descreve anima e animus como arquétipos enraizados no inconsciente, que ligam os aspectos pessoal e impessoal, consciente e inconsciente. A autora também relata como padrões arquetípicos - portanto, anteriores - certas características específicas de cada sexo, entre elas, por exemplo, a masculinidade vista como força e objetividade. Entretanto, novas descobertas de áreas correlatas à psicologia propõem a formulação de outros modos de compreender e de conceituar os arquétipos anima e animus. Segundo Knox (2004), a partir de estudos sobre a genética, descobriu-se que não existe uma codificação efetuada pelos genes de imagens ou processos mentais complexos; portanto, trata-se de uma visão romântica a ideia de que os conteúdos arquetípicos seriam "despertados" em um passe de mágica.

Caminhando lado a lado com a ciência, faz-se necessária uma releitura sobre tais conceitos. Se por um lado, sabe-se que o material genético herdado não transmite imagens ou histórias, ou seja, os genes não carregam informações abstratas nem esquemas complexos predeterminados, por outro, permanecem as evidências de que há diferenças estruturais entre o cérebro masculino e o feminino. Esse fato aponta para novas possibilidades sem encerrar os questionamentos acerca da sexualidade humana. É preciso olhar para a biologia e para a psicologia de maneira integrada, pois se o cérebro molda a psique, a psique também molda o cérebro.

A literatura traz diversos autores críticos à visão tradicional porque há muita confusão na compreensão dos conceitos de anima e animus. São observações importantes e devem ser analisadas de perto. James Astor (2000) reconhece o conceito de arquétipo como confuso e difícil de descrever. Já Verena Kast (2000) acredita que junguianos compreendem o conceito de modo diferente. Valery von Raffay (2000) aponta contradições na obra de Jung ao se referir ao arquétipo e à manifestação arquetípica, sendo que não há possibilidade de o arquétipo herdar ideias inatas ou um mundo anterior àquele já formado e tido como verdadeiro ou exemplar. John Beebe (2000) afirma que se deve evitar a exposição ao reducionismo arquetípico e concorda com von Raffay (2000) quando diz que uma compreensão inadequada do conceito de arquétipo pode levar a se desconsiderar problemas constituídos em relações pessoais. Seguindo a mesma tônica, Fillus (2012, p. 42, citado por Tacey, 1997, p. 20) afirma que

A ideia romântica de que os arquétipos estejam fixados em um espaço de sono eterno e que essas entidades estáveis podem ser acessadas por qualquer pessoa, a 
qualquer momento e em qualquer lugar, precisa ser comparada à ideia de Jung [de] que os arquétipos são incognoscíveis e além da experiência humana.

Tacey também é vigoroso em sua crítica às tentativas de engrandecer comportamentos e atitudes de figuras mitológicas que representam modos de ser imutáveis, sem se considerar os elementos culturais. O autor inclusive salienta que as imagens arquetípicas não podem produzir estereótipos. A sensação é de que tais imagens não são bem compreendidas e acabam sendo tratadas como psicologismos. Um dos primeiros autores a contestar os conceitos postulados por Jung foi James Hillman, para quem anima e animus são arquétipos que devem existir para ambos os sexos. Assim sendo, não há como supor que o homem seja regido por logos e a mulher por Eros, mesmo que sejam entendidos como elementos que compõem tanto o masculino quanto o feminino. Esta ideia contradiz a própria definição da universalidade do arquétipo (Hillman, 1990).

Na tentativa de solucionar essa questão de imagens do masculino e do feminino supostamente estereotipadas, propõem-se olhar para o aspecto arquetípico como a sizígia (arquétipo da alteridade), os opostos juntos na psique e a possibilidade de produção interior, de onde afloram os sistemas arquetípicos anima e animus, carregados de um aspecto numinoso mobilizador do imaginário e da fantasia por onde a vida psíquica pode se integrar. É como ser aquele que não se pode ser: a mulher que não pode ser homem e o homem que não pode ser mulher.

Ao se rever os conceitos de anima e animus deve-se conceber a identidade de gênero como flexível e que tanto homens quanto mulheres teriam anima e animus como par de opostos prototípicos (Young-Eisendrath, 2002). Isso não quer dizer que a divisão entre sexos também seja flexível, ao contrário, a contrassexualidade é um complexo a respeito do sexo oposto. Young-Eisendrath (2002) chama atenção para o fato de a biologia ainda ser determinante nas diferenças sexuais e, por isso, os arquétipos de anima e animus podem ser entendidos também como substrato biológico da sexualidade. Ao abordar o conceito de gênero, Andrew Samuels (1989) afirma que se trata de uma questão psicossocial; não há uma negação biológica e tampouco motivos para crer em determinismo.

Para Fillus (2012),

As reflexões a respeito da anima e animus podem assumir aspectos diversos. O fato observado nos relacionamentos indica que a fantasia em relação ao outro é um mobilizador importante na dinâmica individual. A maneira como cada indivíduo integra sua 
experiência como fenômeno também interfere no modo como o outro terá sua experiência.

$[\ldots]$

Ao final, compreende-se mais uma vez que a individualidade do sujeito tem muito a complementar essa percepção, que, apesar de genérica, será ressignificada de acordo com cada história, cada drama em ser, de fato, humano (Fillus, 2012, p. 45).

Anima e animus são responsáveis pela criação de projeções na constituição de relacionamentos, especialmente os amorosos. $O$ indivíduo é traçado no limiar do arquetípico e do cultural e no caminho do seu desenvolvimento encontra uma trajetória plástica e multifacetada. São muitas as possibilidades de reflexão acerca de anima e animus: a fantasia em relação ao outro é um mobilizador importante na dinâmica individual; o modo como cada um integra sua experiência como fenômeno também interfere na experiência do outro; transformações culturais e a compreensão para o tema também são importantes. Ou seja, a discussão não se encerra sobre um ponto de vista imutável, ao contrário, enquanto houver meios de transformação, o debate deverá permanecer aberto. Tudo indica, portanto, que a individualidade do sujeito complementa a percepção que ganha novos significados de acordo com cada história.

Sendo relação a palavra-chave para tudo que existe acerca da psique, o indivíduo se relaciona com seu animus apoiado no reconhecimento da própria realidade, o que equivale a reconhecer a realidade e a autonomia do inconsciente. Para chegar a este ponto, é impreterível que haja o reconhecimento das projeções. Habitualmente, o animus irá projetar-se sobre homens exteriores, quando não for percebido conscientemente pela mulher como parte dela mesma. Tal projeção pode ser percebida ao observar o encantamento, a supervalorização ou a desvalorização desta mulher por um homem.

As projeções de animus se desenvolvem em quatro etapas:

(1) Nasce como a encarnação da força física, como um atleta ou "homem musculoso".

(2) No estágio seguinte desenvolve iniciativa e capacidade de planejamento.

(3) Então, torna-se "o verbo", manifestando-se muitas vezes como professor ou clérigo.

(4) Na sua quarta etapa, o animus manifesta-se como a personificação do "pensamento". 
Nessa última fase, a vida pode ganhar novo sentido, pois o animus assume o papel de mediador de uma experiência religiosa, dando à mulher firmeza espiritual e amparo interior, rompendo com a aparente brandura. É nesse momento que a mulher se abre a novas ideias, uma vez que o animus conecta a mente feminina com a evolução espiritual da sua época. O animus positivo imprime ousadia aos pensamentos, estimulando novos empreendimentos. Essa característica reservou à mulher de épocas antigas as tarefas de prever o futuro e de conversar com os deuses.

Desde a origem, todo homem traz em si a imagem da mulher; não a imagem desta ou daquela mulher, mas a de um tipo determinado. Tal imagem é, no fundo, um conglomerado hereditário inconsciente, de origem remota, incrustada no sistema vivo, tipo de todas as experiências da linhagem ancestral em torno do ser feminino, resíduo de todas as impressões fornecidas pela mulher, sistema de adaptação psíquico herdado... O mesmo acontece quanto à mulher. Ela também traz em si uma imagem do homem. A experiência mostra-nos que seria mais exato dizer: uma imagem de homens, enquanto que no homem se trata em geral da imagem da mulher; sendo inconsciente, esta imagem é sempre projetada inconscientemente no ser amado; ela constitui uma das razões essenciais da atração passional e de seu contrário. (Jung, 1961/2006, p. 351) (Destaques do autor).

Entre as funções do animus e da anima está a de estabelecer uma relação entre consciência individual e inconsciente coletivo. De modo similar, a persona representa uma zona intermediária na busca de adaptação social, ou seja, entre o eu e o mundo exterior. O caminho inverso é feito por animus e anima que devem conduzir as imagens do inconsciente coletivo ao consciente do eu. Há sempre um aspecto positivo e outro negativo e um aspecto primitivo e outro diferenciado nas manifestações arquetípicas, inclusive animus e anima.

Para Jung,

Em sua primeira forma inconsciente o animus é uma instância que engendra opiniões espontâneas, não premeditadas; exerce influência dominante sobre a vida emocional da mulher, enquanto que a anima é uma instância que engendra espontaneamente sentimentos que exercem sua influência sobre a compreensão do homem e levam à sua distorção (Jung, 1961/2006, p. 351).

As projeções do animus se dão principalmente em personalidades religiosas e em heróis, inclusive celebridades das áreas da música, artes e esportes. Já a anima ocupa um espaço que, na mulher, é 
vazio, inconsciente, ermo e solitário. No decorrer do processo de individuação, alma e consciência do eu se aliam e verifica-se, portanto, uma porção feminina no homem e masculina na mulher. Enquanto a anima reúne, o animus na mulher individualiza. Como são configurações opostas, no nível da realidade consciente constituem um cenário conflituoso, ainda que a relação consciente do parceiro seja equilibrada.

A anima é o arquétipo da vida ... pois a vida se apodera do homem através da anima, se bem que ele pense que a primeira lhe chegue através da razão (mind). Ele domina a vida com o entendimento, mas a vida vive nele através da anima. E o segredo da mulher é que a vida vem a ela através da instância pensante do animus, embora ela pense que é o Eros que Ihe dá vida. Ela domina a vida, vive, por assim dizer habitualmente, através do Eros: mas a vida real, que é também sacrifício, vem à mulher através da razão que nela é encarnada pelo animus (Jung, 1961/2006, p. 351-352).

Capacidade de decisão, iniciativa, coragem e honestidade nascem do lado positivo do animus que, no seu aspecto maior, personifica uma elevada profundidade espiritual. É por meio dele que a mulher se conscientiza dos processos básicos de desenvolvimento da sua posição objetiva, tanto no quesito cultural quanto no pessoal, para encontrar a trajetória que a levará e a elevará a uma atitude intensamente espiritual em relação à vida. Para tanto, seu animus talvez já não emita mais opiniões absolutas. Nesse processo, amparada pela coragem e pela grandeza de espírito, a mulher poderá avaliar a intangibilidade das suas convicções, se tornará mais flexível e apta a aceitar os conselhos vindos do seu inconsciente, especialmente aqueles que contradizem as ideias do seu animus.

Anima e animus vivem num mundo bem diverso do mundo exterior, num mundo em que o pulso do tempo bate infinitamente devagar, em que nascimento e morte de indivíduos contam pouco. Não admira que seu ser seja estranho, tão estranho que sua entrada na consciência significa muitas vezes algo como psicose (Jung, 1934/1954/2002, p. 280, § 519).

Originalmente, o animus é uma formação espontânea, involuntária de opiniões que exercem uma poderosa influência sobre os sentimentos, projetando-se sobre personalidades religiosas e heróis. A anima também é uma formação espontânea, mas que influencia ou distorce a razão. Nos dois casos, o aspecto incestuoso desempenha um papel decisivo: a projeção ocorre na mulher 
jovem sobre o pai; na mulher de mais idade sobre o filho; no homem jovem sobre a mãe; no mais velho, sobre a filha.

"O primeiro foi seu pai / O segundo seu irmão / O terceiro foi aquele que a Tereza deu a mão." (Anônimo, s.d.).

Enquanto a anima no homem procura juntar, o animus na mulher exige individualizar, distinguir. São contrários e isso gera conflitos. Embora o consciente não se identifique com o inconsciente, há um confronto que deve ser levado em consideração, pois tem papel fundamental no desenvolvimento do sujeito. $O$ consciente deve conseguir se expressar seja verbalmente, gestualmente ou por meio dos sentimentos. Do contrário, a antiga cisão reaparece e com ela todas as consequências que o desprezo ao inconsciente pode acarretar. Mas caso sejam feitas muitas concessões ao inconsciente, poderá ocorrer uma inflação da personalidade, no sentido positivo. De qualquer modo, sempre haverá um conflito entre "prós" e "contras", o que é certamente desconfortável, mas inevitável, pois não é possível fugir de si mesmo o tempo todo. É uma cruz a ser carregada. De acordo com a alquimia, essa oposição tem uma estrutura quádrupla, possui quatro elementos e forma a imagem de uma cruz que corresponde à realidade psíquica, à criação do ego a partir do inconsciente, tanto por sua forma cruzada, quanto por seu aspecto de suplício.

Pode-se dizer então que carregar a cruz é um símbolo que ilustra adequadamente a totalidade e a paixão. Assumir uma postura de fuga diante da vida deixa a pessoa amarga. Entretanto, viver bem consigo mesmo exige um esforço no sentido de destinar para si paciência, amor, fé, esperança e humildade.

Essa conduta pode trazer questionamentos sobre a própria felicidade, autoacolhimento e reconhecimento de carências, o que poderá descortinar um "demônio" interno provocador e tornar a autoconvivência insuportável até que se ganhe a consciência de que não se deve dar ao outro aquilo que não se dá a si mesmo, seja o bem, seja o mal.

\section{A mãe}

O complexo de Édipo é apenas um modelo da relação entre filho e mãe que produz os entrelaçamentos fatais do espírito com a matéria, chamados neuróticos a partir do século XX. Tentativas desesperadas, agoniadas e trágicas para desatar o nó primordial da neurose mostram como são fortes as suas necessidades mútuas. O laço original de espírito e matéria é personificado pelo abraço apertado ou pela conjunção erótica entre mãe e filho. $\bigcirc$ espírito está tão imerso no corpo material, seja se deliciando, seja se 
contorcendo para sair, que dificilmente podemos descobrir outras interpretações do espírito.

Para James Hillman (1998), declarar negativo o complexo é congelá-lo no inferno. O autor propõe que se repense a questão do puer aeternus em relação à mãe. A ideia de puer negativo e positivo também deve ser revista.

Mas afinal quem é o pai que falta? Não é o pessoal, mas aquele espiritual, o Deus morto que oferece um foco tal que não incita o filho a buscar respostas em sonhos e oráculos mais do que nas orações, códigos, tradição e ritual. Hillman (1998) questiona o que acontece quando puer, como estrutura fundamental da psique, perde sua autoidentidade, sua posição dentro da totalidade puer/senex (jovem/velho) e é sutilmente substituído pela figura do filho da grande mãe. "Quando a mãe substitui o pai, a magia substitui o logos (verbo) e os filhos sacerdotes invadem o espírito puer." (Hillman, 1998, p. 75).

Como não conseguem retroceder para reviver o pai morto da tradição, os filhos caminham para dentro das mães do inconsciente coletivo procurando uma total compreensão e a garantia de segurança. "A mãe encoraja o filho a seguir em frente e a abraçar tudo, que para ela, significa todas as coisas, enquanto para o pai, ao contrário, tudo significa nada, a menos que seja discriminado." (Hillman, 1998, p. 77)

Sem o pai perde-se também as habilidades de reconhecer um chamado e de discriminar vozes, atividade essencial para a psicologia. $\bigcirc$ espírito que não tem pai, não tem guia.

Sem o pai perdemos também aquela capacidade que a Igreja reconheceu como "discriminação dos espíritos": a habilidade para reconhecer um chamado quando o ouvimos e para discriminar as vozes, atividade tão necessária para a psicologia precisa do inconsciente (Hillman, 1998, p. 76).

Inércia passiva e dinâmica compulsiva da natureza é característica do reino da "Grande Deusa". Há um ciclo protetor que nutre e gera animais e plantas, desde a semente até a morte. Este é um lugar cheio de afinidades com o belo, atemporal e emocional, e suas preferências apontam para laços de parentesco, mas também para o obscuro, opaco, estancado. A mãe, como aquela que nutre tal qual a vida natural, fornece ao puer dose excessiva de alimento e, com isso, reforça alguns traços básicos do filho, exigindo que ele se comporte como dependente. O complexo materno dificulta a precisão do espírito, elemento de pouca compreensão para a "Grande Deusa" que o apreende em seu relacionamento. O espírito deve ter efeitos no mundo material 
(vida e pessoas). Ainda que o filho reconhecesse a mãe em seus atos, fugisse e se refugiasse em abstrações e fantasias impessoais, ele continuaria sendo o filho impregnado pelo animus da "Deusa". Mãe e filho constituem-se como modos de percepção.

A íntima associação entre mãe e filho na psique é imaginada como incesto e experimentada como êxtase e culpa. O êxtase segue as duas direções verticais, a divina e a infernal, mas a culpa não encontra alívio. A grande mãe transforma a dívida do puer para com o transcendente - o que deve aos deuses por seus dons numa dívida de sentimento, numa culpa em relação aos símbolos na vida material. Ele paga a mais para a sociedade através da família, do emprego, dos deveres civis, e evita seu destino (Hilman, 1998, p. 79).

\section{Considerações finais}

Os heróis são andarilhos (Gilgmesh, Dionísio, Hércules, Mitra etc.) , e o caminhar errante é símbolo da busca incessante que nunca encontra seu objeto e da nostalgia da mãe que se perdeu. De acordo com Jung (1912/1952/2013), esta mãe perdida é o objeto secreto da caminhada.

Há uma parte da libido, a libido renegada, que se afasta das tarefas heroicas e deseja voltar e mergulhar na mãe de maneira incestuosa, mas não consegue, pois é intimidada pelo tabu. Uma vez que a libido não atinge seu objetivo, segue caminhando errante e ansiando para sempre. Essa explicação dinâmica é a primeira e clássica elaboração junguiana da figura arquetípica do puer aeternus: o componente eternamente jovem da psique humana, homem ou mulher, jovem ou velho, que está sempre caminhando e que está ligado à mãe arquetípica.

A psicologia junguiana propõe considerar o caminhar errante como símbolo do anseio nostálgico, que pode não ter nada a ver com incesto. Vejamos o caso de Ulisses, o andarilho primordial. Sentado na beira do mar, na ilha [Ogígia] onde mora Calipso [ninfa marítima], o olhar desconsolado, ele está repleto de nostalgia. "Pensa que não existe nada pior para o mortal do que o caminhar errante. Anticléia [mãe], Telêmaco [filho], Eumeu [amigo] sofrem de saudades de Ulisses" (Hillman, 1998 p. 186). Mas Ulisses deseja apenas voltar para casa, não pela sua mãe, mas por seu lar e pela ilha onde nasceu. Mesmo que Calipso e Ogígia possam preencher suas necessidades libidinais incestuosas e renegadas. "Ulisses sofre e anseia por seu lar, pela enorme cama redonda onde dormia com 
Penélope [esposa]. A nostalgia nasce da separação das duas metades, da falta de conjunção" (Hillman, 1998, p. 188).

O papel do arquétipo materno regressivo e devorador é claramente discriminado da matriz criadora. Jung insere tal dualidade dentro de uma fantasia em cada metade da vida, que também é uma dualidade, a do puer/senex: estruturas da consciência válidas em todas as fases da vida. Para o jovem "entrar na mãe" significa praticar um ato incestuoso; para o velho "entrar na mãe" representa o caminho da renovação, da individuação. Parece que o mundo hoje vive um período em que seu ego heroico atingiu o ápice e os complementares senex e puer ganharam grande relevância. Jung diria que essa fase da consciência coletiva corresponde a da segunda metade da vida.

Para os indivíduos que vivem na atualidade e estão inseridos nesta cultura, a batalha com o dragão e a posição heroica da primeira metade da vida estão arquetipicamente erradas, apesar da idade do indivíduo. Esta é uma postura obsoleta, completamente fora de sintonia com o tempo atual, e cada vitória sobre o dragão simboliza uma derrota diante da tarefa da cultura atual: tornar-se consciente do senex em todo o seu significado arquetípico e a ele relacionar a fenomenologia do puer. Na atualidade (século XXI) as características do puer - são valorizadas (rapidez, volatilidade); já as características do senex ,viram sombra.

A nova mulher vive no mundo do homem, onde ela se volta contra as forças da feminilidade que estão situadas no âmago de sua identidade. A relação com os filhos também é permeada pelo desenvolvimento de um complexo filial. Expectativas irreais que ultrapassam a individualidade dos filhos são jogadas nesse emaranhado circular, dificultando o processo de desenvolvimento de cada um.

No entanto, a capacidade de libertação não depende da relação materno-filial biológica-arquetípica, ela depende da natureza individual de cada um. Vê-se nos consultórios indivíduos que conseguem se libertar, apesar de todo cenário difícil e do constrangimento provocado pelo aprisionamento do animus da mãe. São indivíduos que possuem uma vitalidade, ligada a um fator de atividade do eu que lhes confere a capacidade de superação.

Na vida real, uma mulher consegue reconhecer que está chegando a um equilíbrio entre os dois arquétipos dentro de si mesma quando ela já não é impelida a uma ação, fala ou defesa de um coletivo ideal, antes de perceber o que realmente valoriza em si mesma. Quando sua natureza feminina não é anulada por seu animus, ela terá uma sensação de paz e de intimidade consigo mesma. Até mesmo os relacionamentos exteriores podem não ser 
essenciais nesse momento, pois a mulher pode não precisar projetar seu animus ou sua feminilidade para fora de si mesma.

Se, de fato, é o feminino reprimido e violentado que está prestes a revidar a nossa civilização unilateral, as mulheres têm uma séria responsabilidade de ajudar os homens na reconstrução de um equilíbrio. No entanto, é necessário que ela seja uma mulher em seu corpo e alma e no seu papel social e cultural. Além disso, a mulher precisa reconhecer que seu poder pode tanto construir quanto destruir. Apenas então, ela poderá ter um relacionamento significativo com seu animus e com os homens e a sociedade. Então o animus, por sua vez, será libertado de sua posição de controle, para servir ao ego feminino da mulher, a fim de que ela possa satisfazer sua individualidade e realizar seu destino pela criação de uma nova consciência.

\section{Referências}

Anônimo. (s.d.). Terezinha de Jesus. Recuperado de https://www.ouvirmusica.com.br/cantigas-populares/984009/.

Astor, J. (2000). Comment on Why it is difficult to see the anima as a helpful object. Journal of Analytical Psychology, 45(4), 561-564. doi.org/10.1111/1465-5922.00191.

Beebe, J. (2000). Response to Anita von Raffay's paper. Why it is difficult to see the anima as a helpful object. Journal of Analytical Psychology, 45(4), 565-568. doi.org/10.1111/1465-5922.00192.

Fillus, M. A. (2012). Anima e animus na Contemporaneidade. Junguiana, 30(2), 39-46.

Hillman, J. (1990). Anima: anatomia de uma noção personificada. São Paulo: Cultrix.

Hillman, J. (1998). O livro do puer: ensaios sobre o arquétipo do puer aeternus. São Paulo: Paulus.

Jung, C. G. (1987). O eu e o inconsciente (OC, Vol. VII/2). Petrópolis: Vozes.

Jung, C. G. (2002). Os arquétipos e o inconsciente coletivo (OC, Vol. XIX/1). Petrópolis, RJ: Vozes (Trabalho original publicado em 1934; revisado em 1954).

Jung, C. G. (2006). Memórias, sonhos, reflexões (2a ed.). Rio de Janeiro: Nova Fronteira. (Trabalho original publicado em 1961).

Jung, C.G. (2011). Aion, estudos sobre o simbolismo do si-mesmo (OC, Vol. 2). Petrópolis, RJ: Vozes. (Trabalho original publicado em 1951). 
Jung, C. G. (2013). Símbolos da transformação (OC, Vol. V). Petrópolis, RJ: Vozes. (Trabalho original publicado em 1912; revisado em 1952).

Jung, E. (1995). Anima e Animus. São Paulo. Cultrix.

Kast, V. (2000). Comment on Von Raffay: 'Why it is difficult to see the anima as a helpful object. Journal of Analytical Psychology, 45(4), 569-571.

Knox, J. (2004). From archetypes to reflective function. Journal of Analytical Psychologym, 49(1), 1-19.

Tacey, D. J. (1997). Remaking men: Jung, spirituality and social change. London: Routledge.

von Raffay, A. (2000). Why it is difficult to see the anima as a helpful object. Journal of Analytical Psychology, 45(1), 541-560.

Minicurrículo: Irene Gaeta - Analista didata do Instituto Junguiano de São Paulo (IJUSP); membro da Associação Junguiana do Brasil (AJB); filiada à International Association for Analytical Psychology (IAAP/Zurich). Doutora em Psicologia Clínica pela Pontifícia Universidade Católica de São Paulo (PUC/SP); mestre em Gerontologia pela PUC/SP; especialista em Práxis Artísticas e Terapêutica: Interfaces da Arte e da Saúde pela Faculdade de Medicina da Universidade de São Paulo; arteterapeuta formada pelo Instituto Sedes Sapientiae. Psicóloga. Coordenadora do Núcleo de Estudos em Arte e Psicologia Analítica (NAPA) do IJUSP e do Departamento de Arte e Psicologia da AJB. Professora do curso de Psicologia da Faculdade de Ciências Humanas e da Saúde da PUC/SP. Coordenadora da Pós-Graduação em Psicologia Analítica e em Psicogerontologia da Universidade Paulista. Autora dos Livros: "Memória corporal o simbolismo do corpo na trajetória da vida" (Editora Vetor); "Psicoterapia junguiana: novos caminhos na clínica o uso do desenho de mandalas e calatonia" (Editora Vetor); organizadora da Coletânea "Gerontologia" (Editora Vetor); coautora dos livros: "Sonhos e arte - diário de Imagens" (Primavera Editorial); "Arteterapia e mandalas uma abordagem junguiana" (Editora Vetor); "Corpo em Jung" (Editora Vetor); "Etapas da família - Quando a tela nos espelha" (Editora Appris). Atende em consultório adolescentes e adultos. mail: estudosjunguianos.irenegaeta@gmail.com 